Document downloaded from:

http://hdl.handle.net/10251/89676

This paper must be cited as:

Gallego Ibáñez, M.; Mora Soler, L.; Hayes, M.; Reig Riera, MM.; Toldrá Vilardell, F. (2017). Effect of cooking and in vitro digestion on the antioxidant activity of dry-cured ham byproducts. FOOD RESEARCH INTERNATIONAL. 296-306.

doi:10.1016/j.foodres.2017.04.027

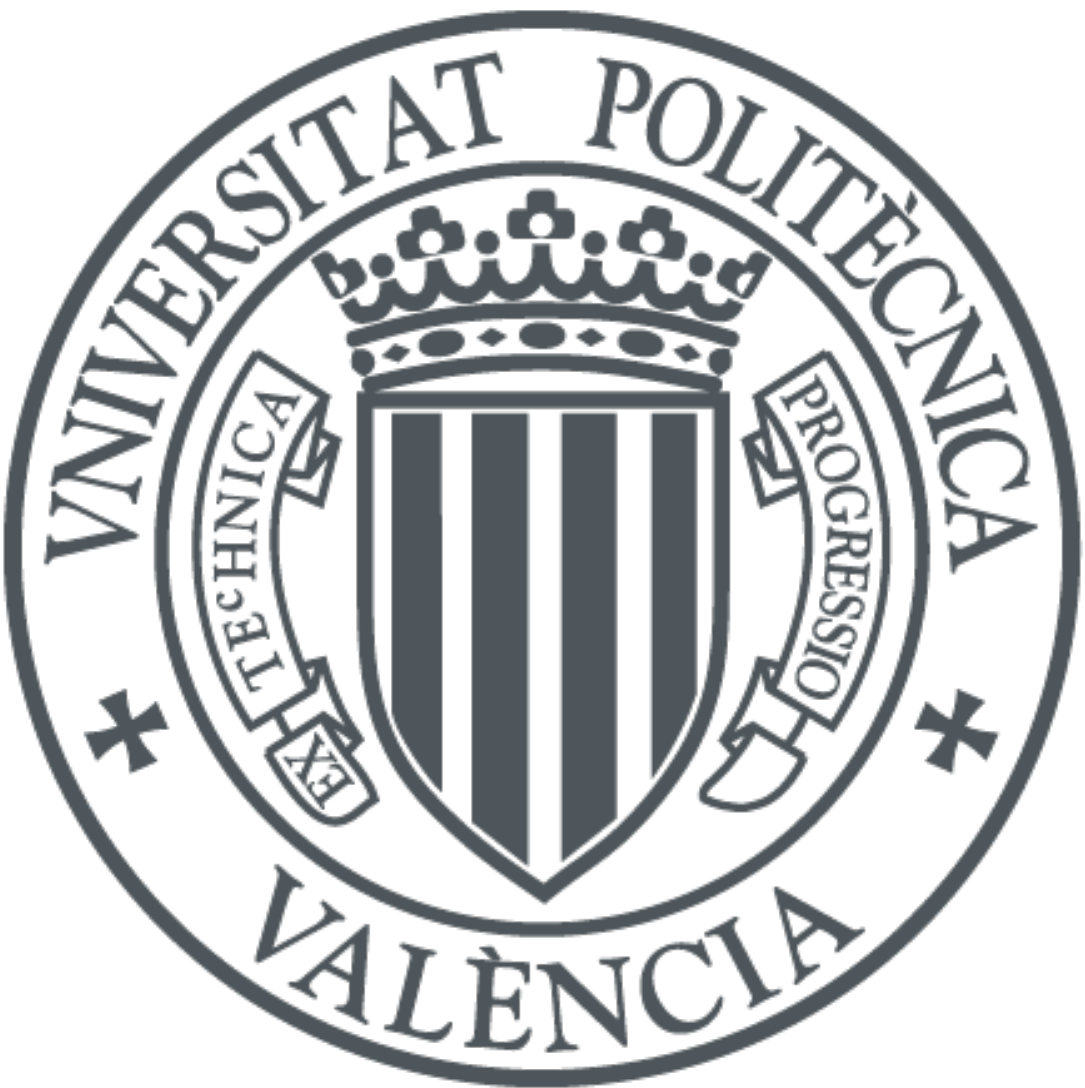

The final publication is available at

http:dx.doi.org/10.1016/j.foodres.2017.04.027

Copyright

Additional Information 


\section{Effect of cooking and in vitro digestion on the antioxidant activity of} dry-cured ham by-products

1. Instituto de Agroquímica y Tecnología de Alimentos (CSIC), Avenue Agustín Escardino 7, 46980, Paterna (Valencia), Spain

2. Teagasc, The Irish Agricultural and Food Development Authority, Food BioSciences Department, Ashtown, Dublin 15, Ireland

3. Instituto de Ingeniería de Alimentos para el Desarrollo, Universidad Politécnica de Valencia,

${ }^{*}$ Corresponding author: Tel: +34963900022 ext.2114; fax: +34963636301.

E-mail address: lemoso@iata.csic.es 


\section{Abstract}

32 Dry-cured ham by-products have been traditionally used in Mediterranean household 33 cooking of broths and stews. The aim of this work was to evaluate the effect of cooking 34 treatments and in vitro gastrointestinal digestion on the antioxidant activity of natural peptides found in dry-cured ham by-products including bones. The antioxidant activity was tested using five different assays and results demonstrated that cooking using conventional household methods increased the antioxidant activity of ham by-products when assessed using different antioxidant assays with the exception of the ABTS radical scavenging measurement assay. Simulated gastrointestinal digestion showed no significant effect on the antioxidant activity of ham by-products and antioxidant activity decreased when assessed using the ORAC and $\beta$-carotene bleaching assays. Analysis by MALDI-TOF MS revealed a considerable breakdown of peptides due to the action of gastrointestinal enzymes, mainly in samples cooked at $100{ }^{\circ} \mathrm{C}$ for $1 \mathrm{~h}$. In addition, 459 peptides derived from 57 proteins were identified using mass spectrometry in tandem. These peptides were derived from collagen protein and were found to be responsible for the differences in antioxidant activities observed between uncooked and cooked samples after digestion. The results show the potential of dry-cured ham bones as a source of antioxidant peptides that retain their bioactivity after household cooking preparations and gastrointestinal digestion.

53 Keywords: Antioxidant, peptides, mass spectrometry, quantification, cooking, 54 gastrointestinal digestion, by-products. 


\section{Introduction}

57 Every year the meat industry produces tons of by-products including bones, skin, blood and horns resulting from both animal slaughtering and trimming or deboning during the processing of meat products (Lafarga \& Hayes, 2014). This waste represents a high cost for the meat processing sector and serious environmental problems (Mora, Reig \& Toldrá, 2014). As a result, meat processing industries are making a strong effort to convert wastes and by-products into useful products for animal feeds, human foods, pharmaceutical products, fertilisers and biodiesel generation (Arvanitoyannis \& Ladas, 2008; Toldrá, Aristoy, Mora, \& Reig, 2012). Regarding edible products, the production of protein hydrolysates from pork, beef or lamb by-products using commercial proteases is one of the most studied and promising markets (Di Bernardini, Harnedy, Bolton, Kerry, O’Neill, Mullen, \& Hayes, 2011). These hydrolysates may be added to enhance the flavor, emulsion stability and water holding capacity of food products as well as for added nutrients to produce valuable products and functional ingredients like bioactive peptides (Zhang, Xiao, Samaraweera, Lee, \& Ahn, 2010; Toldrá \& Reig, 2011; Mora, Reig, \&

Toldrá, 2014). Residues derived from the slicing of hams such as rinds and bones are traditionally used in Mediterranean cooking as ingredients that add flavor to soups, broths, and stews.

A large number of bioactivities including antihypertensive, antimicrobial and antioxidant activities were reported for peptides generated though enzymatic hydrolysis of byproducts to date (Di Bernardini et al., 2011, Mora et al., 2014, Lafarga \& Hayes, 2014). These bioactive peptides need to be resistant to degradation by gastrointestinal proteases and must be absorbed through the intestinal epithelium and reach the bloodstream in an active form to exert physiologically effects (Vercruysse, Van Camp, \& Smagghe, 2005). 
81 including pepsin, trypsin and pancreatin is frequently used to determine the

82 bioaccessibility and availability of bioactive peptides (Escudero, Sentandreu, Arihara, \&

83 Toldrá, 2010; Zhu, Zhang, Zhou, \& Xu, 2016). Among bioactive peptides, those showing antioxidant capacity are interesting as their use in foods can provide natural protection against oxidative processes, which are associated with changes in sensory traits and nutritional value, quality deterioration and consequently, economic losses for food industries. Moreover, in terms of health effects in the human body, antioxidant peptides are thought to decrease the adverse effects of reactive oxygen species (ROS) on normal physiological functions and thus the risk for development of some degenerative diseases (Sarmadi \& Ismail, 2010; Samaranayaka \& Li-Chan, 2011).

The main purpose of the present study was to evaluate the effect of cooking treatments that simulated traditional Mediterranean household cooking of broths and in vitro gastrointestinal digestion on the antioxidant activity and peptide profile of water-soluble extracts obtained from dry-cured ham bones.

\section{Materials and methods}

\subsection{Chemicals and reagents}

Enzymes used for the in vitro gastrointestinal digestion: salivary $\alpha$-amylase, porcine pepsine, porcine pancreatic $\alpha$-amylase, porcine pancreatic lipase, and porcine bile extract were purchased from Sigma-Aldrich, Co. (St. Louis, MO, USA). Trypsin and chymotrypsin enzymes were from Fluka (Sigma-Aldrich, Co., St. Louis, MO, USA). Regarding chemicals used in the antioxidant assays, 2,2-diphenyl-1-picrylhydrazyl (DPPH), potassium ferrycianide, ferric chloride, ( \pm )-6-hydroxy-2,5,7,8tetramethylchromane-2-carboxylic acid (Trolox), 2,2'-Azino-bis(3-ethylbenzothiazoline6-sulfonic acid) diammonium salt (ABTS), fluorescein, 2,2'-azobis(2methylpropionamidine) dihydrochloride (AAPH), $\beta$-carotene, and linoleic acid were 
106 from Sigma-Aldrich, Co. (St. Louis, MO, USA). Potassium persulfate, butylated

107 hydroxytoluene (BHT) and butylated hydroxyanisole (BHA) were purchased from

108 Panreac Quimica SAU (Barcelona, Spain). All used chemicals and reagents were of 109 analytical grade.

110

\section{$111 \quad 2.2$ Sample preparation and cooking procedure}

112 Samples of femoral bones were obtained from six Spanish dry-cured hams with 18

113 months of processing, after the removal of muscles and fat. Bones were minced and

114 subjected to different cooking conditions. A quanitity of $50 \mathrm{~g}$ of minced bones were 115 cooked in water at $100^{\circ} \mathrm{C}$ for $20 \mathrm{~min}$ and $100{ }^{\circ} \mathrm{C}$ for $1 \mathrm{~h}$ in order to simulate Mediterranean

116 household cooking methods.

\section{$117 \quad 2.2$ Extraction of peptides}

118 Five different extraction procedures were tested. Two samples were cooked as described

119 in the preceding section, followed by the extraction of peptides using water. The third

120 sample was only submitted to extraction with water as a control, and the final two samples

121 were subjected to acidic extraction using $0.5 \mathrm{~N} \mathrm{HCl}$ and $0.01 \mathrm{~N} \mathrm{HCl}$ in order to study the

122 influence of different extraction solutions on peptides.

123 A total of $50 \mathrm{~g}$ of minced, dry-cured ham bones were homogenised with $200 \mathrm{~mL}$ of the

124 corresponding extraction solvent and kept at $4{ }^{\circ} \mathrm{C}$ overnight with continuous stirring. The

125 resulting homogenate was centrifuged at $12,000 \mathrm{~g}\left(20 \mathrm{~min}\right.$ at $\left.4{ }^{\circ} \mathrm{C}\right)$ and filtered through

126 glass wool. Precipitation of proteins was done by the addition of 3 volumes of ethanol

127 and maintaining the sample at $4{ }^{\circ} \mathrm{C}$ for $20 \mathrm{~h}$. After centrifugation at $12,000 \mathrm{~g}$ for $10 \mathrm{~min}$

$128\left(4^{\circ} \mathrm{C}\right)$, the supernatant was dried in a rotatory evaporator and finally lyophilised.

$129 \quad 2.3$ In vitro gastrointestinal digestion 
130 All samples were subjected to in vitro digestion according to the methodology described

131 by Minekus et al. (2014) with some modifications. Briefly, $500 \mathrm{mg}$ of sample were 132 suspended in $2 \mathrm{~mL}$ of $0.2 \mathrm{M} \mathrm{NaHCO}_{3}(\mathrm{pH} 7.0)$. A total of $27 \mathrm{U} / \mathrm{mL}$ of salivary $\alpha$-amylase

133 solution and $37 \mu \mathrm{L}$ of $50 \mathrm{mM} \mathrm{CaCl}_{2}$ were added and the mixture was maintained for 3

$134 \mathrm{~min}$ at $37^{\circ} \mathrm{C}$ to simulate the oral phase. Then, the $\mathrm{pH}$ was adjusted to 3.0 with $1 \mathrm{M} \mathrm{HCl}$

135 to expose samples to the gastric phase. For that, porcine pepsine was added to achieve $1362000 \mathrm{U} / \mathrm{mL}$ in the final mixture followed by $4 \mu \mathrm{L}$ of $50 \mathrm{mM} \mathrm{CaCl}_{2}$. After $3 \mathrm{~h}$ of digestion 137 at $37^{\circ} \mathrm{C}$ and constant stirring, the enzyme was inactivated by adjusting $\mathrm{pH}$ to 7.0 with 1

$138 \mathrm{M} \mathrm{NaOH}$. Digestive enzymes were added to the mixture to achieve the following 139 activities in the final mixture: $100 \mathrm{U} / \mathrm{mL}$ of trypsin, $25 \mathrm{U} / \mathrm{mL}$ of chymotrypsin, $200 \mathrm{U} / \mathrm{mL}$ 140 of porcine pancreatic $\alpha$-amylase, $2000 \mathrm{U} / \mathrm{mL}$ of porcine pancreatic lipase and $10 \mathrm{mM}$ of porcine bile extract. A total of $16 \mu \mathrm{L}$ of $50 \mathrm{mM} \mathrm{CaCl}_{2}$ was also added, and after $3 \mathrm{~h}$ at 37

$142{ }^{\circ} \mathrm{C}$ the intestinal digestion was finished by heating for 2 min at $95{ }^{\circ} \mathrm{C}$. The mixture was 143 deproteinised by adding 3 volumes of ethanol maintaining the sample at $4{ }^{\circ} \mathrm{C}$ for $20 \mathrm{~h}$, 144 and centrifuged at $12,000 \mathrm{~g}$ and $4{ }^{\circ} \mathrm{C}$ for $10 \mathrm{~min}$. Finally, the supernatant was dried in a 145 rotatory evaporator and lyophilised.

\section{$146 \quad 2.4$ Antioxidant activity}

147 The antioxidant activity was determined in triplicate using five different methods. For 148 that, stock solutions of $500 \mathrm{mg} / \mathrm{mL}$ in bidistilled water were prepared for all samples, 149 before and after in vitro digestion.

\section{$150 \quad$ 2.4.1 DPPH radical scavenging activity}

151 The DPPH activity of samples was determined as described by Bersuder, Hole, and Smith 152 (1998). Briefly, $100 \mu \mathrm{L}$ of each sample was mixed with $500 \mu \mathrm{L}$ of ethanol and $125 \mu \mathrm{L}$ of 153 DPPH solution (0.02 \% of DPPH in ethanol). The mixture was incubated in the dark for $15460 \mathrm{~min}$ and the reduction of DPPH radicals was measured at $517 \mathrm{~nm}$. A reduction in the 
155 absorbance of the reaction mixture indicates higher free radical scavenging activity.

156 Bidistilled water was used as the negative control and BHT as a positive control. The

157 scavenging activity was calculated using the following equation: DPPH radical

158 scavenging activity $(\%)=($ Absorbance control - Absorbance sample) $/$ Absorbance

159 control x 100.

$160 \quad$ 2.4.2 Ferric-reducing antioxidant power

161 The reducing power was measured based on the ability to reduce ferric iron to ferrous 162 iron (Huang, Tsai, \& Mau, 2006). Briefly, $70 \mu \mathrm{L}$ of each sample was mixed with $70 \mu \mathrm{L}$

163 of phosphate buffer (200 mM, pH 6.6) and $70 \mu \mathrm{L}$ of potassium ferricyanide $(10 \mathrm{mg} / \mathrm{mL})$.

164 The mixture was incubated at $50{ }^{\circ} \mathrm{C}$ for $20 \mathrm{~min}$, and $70 \mu \mathrm{L}$ of trichloroacetic acid (100

$165 \mathrm{mg} / \mathrm{mL}$ ) was added before a centrifugation step was carried out at $200 \mathrm{X} \mathrm{g}$ for $10 \mathrm{~min}$.

166 Then, $200 \mu \mathrm{L}$ of the supernatant was mixed with $200 \mu \mathrm{L}$ of bi-distilled water and $40 \mu \mathrm{L}$

167 of ferric chloride ( $1 \mathrm{mg} / \mathrm{mL})$. The absorbance was measured at $700 \mathrm{~nm}$ after $10 \mathrm{~min}$ of 168 incubation. Higher absorbance values indicated higher ferric-reducing power. BHT was 169 used as the positive control.

$170 \quad$ 2.4.3 ABTS radical scavenging capacity

171 The ABTS assay was performed as described by Re et al. (1999) with slight modifications.

172 Briefly, $7 \mathrm{mM}$ of ABTS was dissolved in potassium persulfate (2.45 mM). The mixture 173 was kept in the dark at room temperature for $12-16 \mathrm{~h}$ to produce $\mathrm{ABTS}^{++}$. The $\mathrm{ABTS}^{++}$ 174 solution was diluted with phosphate buffer saline (PBS) (50 mM, pH 7.4) to obtain an 175 absorbance of $0.70 \pm 0.02$ at $734 \mathrm{~nm}$. An amount of $10 \mu \mathrm{L}$ of sample was mixed with 990 $176 \mu \mathrm{L}$ of $\mathrm{ABTS}^{++}$solution and the absorbance was measured at $734 \mathrm{~nm}$ after 6 min of 177 incubation. PBS was used as negative control and ascorbic acid as positive control. Trolox 178 at a concentration between 0.05 and $2 \mathrm{mM}$ was used to obtain a calibration curve. The 179 ABTS radical scavenging activity was calculated and plotted against the concentration of 
180 trolox and the results were expressed as nanomoles of TEAC (trolox equivalent 181 antioxidant capacity) per mg of sample.

\subsubsection{Oxygen radical absorbance capacity assay (ORAC)}

183 ORAC assay using fluorescein (FL) was carried out according to the method described

184 by Dávalos, Gómez-Cordovés, and Bartolomé (2004) with slight modifications. $140 \mu \mathrm{L}$ 185 of sample prepared in phosphate buffer $(75 \mathrm{mM}, \mathrm{pH} 7.4)$ was mixed with $70 \mu \mathrm{L}$ of 186 fluorescein (200 nM) and incubated at $37^{\circ} \mathrm{C}$ for $15 \mathrm{~min}$. Then, $70 \mu \mathrm{L}$ of AAPH (80 mM) 187 was added and the fluorescence was measured at 1 min intervals for 100 min using 188 excitation and emission wavelengths of 485 and $538 \mathrm{~nm}$, respectively. Trolox $(2-16 \mu \mathrm{M})$ 189 was used as standard and tryptophan as positive control. The area under curve (AUC) was 190 calculated for each sample by integrating the relative fluorescence curve. The ORAC-FL 191 values were calculated and plotted against the concentration of trolox to obtain a standard 192 curve and the results were expressed as nanomoles of TE (Trolox equivalents) per mg of 193 sample.

\section{$194 \quad 2.4 .5$. $\beta$-carotene bleaching assay}

195 The ability of samples to prevent $\beta$-carotene bleaching was assayed as described by 196 Koleva, Van Beek, Linssen, De Groot, and Evstatieva (2002) with some modifications.

197 A total of $0.5 \mathrm{mg}$ of $\beta$-carotene, $20 \mu \mathrm{L}$ of linoleic acid and $200 \mu \mathrm{L}$ of Tween 80 were 198 dissolved in $1 \mathrm{~mL}$ of chloroform to obtain the $\beta$-carotene/linoleic acid solutionprepared 199 by dissolving. Then, chloroform was totally evaporated in a rotatory evaporator at $40{ }^{\circ} \mathrm{C}$, 200 and $100 \mathrm{~mL}$ of bidistilled water was added and vigorously stirred. Finally, $50 \mu \mathrm{L}$ of 201 sample was mixed with $250 \mu \mathrm{L}$ of the $\beta$-carotene solution and the absorbance was 202 measured at $450 \mathrm{~nm}$ immediately $\left(\mathrm{t}_{0}\right)$ and after $180 \mathrm{~min}$ of incubation at $50{ }^{\circ} \mathrm{C}\left(\mathrm{t}_{\mathrm{f}}\right)$. 203 Bidistilled water was used as blank and BHA as positive control. The antioxidant activity 
was calculated as: Antioxidant activity $(\%)=\left(1-\left(\right.\right.$ Absorbance sample $t_{0}-$ Absorbance sample $\mathrm{t}_{\mathrm{f}}$ ) / (Absorbance blank $\mathrm{t}_{0}$ - Absorbance blank $\left.\mathrm{t}_{\mathrm{f}}\right)$ ) x 100 .

\subsection{MALDI-TOF MS analysis}

207 In order to analyse the profile of peptides obtained after the different extractions, samples 208 before and after gastrointestinal digestion were analysed by matrix-assisted laser 209 desorption/ionization time-of-flight mass spectrometer (MALDI-TOF MS) as described 210 by Gallego, Mora, Aristoy, and Toldrá (2015a). Thus, an aliquot of $15 \mu \mathrm{L}$ of sample from

211 stock solutions was concentrated using Zip-Tip C18 with standard bed format (Millipore 212 Corporation, Bedford, MA) and $1 \mu \mathrm{L}$ of each sample was located into a MALDI plate for 213 analysis.

\section{$214 \quad 2.6$ nLC-MS/MS analysis}

215 The identification of peptides was performed by nanoliquid chromatography-tandem 216 mass spectrometry (nLC-MS/MS) according to the methodology used by Gallego, Mora, 217 Aristoy, and Toldrá (2015b). In this regard, $5 \mu \mathrm{L}$ of control sample (peptides extracted with $\mathrm{H}_{2} \mathrm{O}$ ) and samples submitted to cooking ( $100{ }^{\circ} \mathrm{C}$ during 20 min and $1 \mathrm{~h}$, respectively)

219 and all after the in vitro digestion at a concentration of $0.3 \mathrm{mg} / \mathrm{mL}$ in $\mathrm{H}_{2} \mathrm{O}$ with $0.1 \%$ of 220 TFA were injected into the nLC-MS/MS system.

\section{$221 \quad 2.7$ Data analysis}

Mascot Distiller v2.4.2.0 software (Matrix Science, Inc., Boston, MA, USA; http://www.matrixscience.com) was used in the identification and quantification of the natural peptides extracted from broths. The identification of peptides and protein of origin was done using UniProt database with a significance threshold of $P<0.05$ and a tolerance

226 on the mass measurement of $100 \mathrm{ppm}$ in MS mode and $0.3 \mathrm{Da}$ for MS/MS ions. Mammalia taxonomy and none specific enzyme were selected. 
228 The relative quantification was performed using the label-free approach described by

229 Gallego et al. (2015b). This label-free approach is based on the measurement of the 230 integrated areas of extracted ion chromatograms (XICs), whose combination allows the

231 ratios for individual peptides to be determined. For that, during identification Mascot 232 search engine assigns peptide matches to the origin protein, requiring robust search 233 parameters as quantification is done at peptide level. Quantitative data was obtained using 234 Peak View 1.1 software (AB Sciex, Framingham, MA, USA) and then analysed using 235 Marker View 1.2 software (AB Sciex, Framingham, MA, USA). Principal Component 236 Analysis (PCA) and loading plot analysis were performed using SIMCA-P+ 13.0 237 (Umetrics AB, Sweden) software. Finally, statistical analysis including one-way analysis 238 of variance (ANOVA) and Fisher's multiple range test were carried out using XLSTAT 239 program (2011).

240 3. Results and discussion

$241 \quad 3.1$ Effect of cooking treatment and simulated gastrointestinal digestion on the 242 antioxidant activity

243 In order to optimise the extraction of peptides from dry-cured ham bones, the effect of 244 acid concentrations (0.5 $\mathrm{N}$ and $0.01 \mathrm{~N} \mathrm{HCl}$, respectively) on the extracted peptides was 245 also evaluated. Additionally, two different cooking treatments in boiling water $\left(100^{\circ} \mathrm{C}\right)$ 246 for $20 \mathrm{~min}$ and $1 \mathrm{~h}$ respectively were studied. All samples were also subjected to in vitro 247 gastrointestinal digestion to assess the antioxidant capacity before and after the simulated 248 digestion.

249 Different methodologies are currently used to assess the in vitro antioxidant activity of 250 protein hydrolysates or peptides, which are classified into two groups depending on the basis of the chemical reactions involved: methods based on hydrogen atom transfer

252 (HAT) and methods based on electron transfer (ET) (Huang, Ou, \& Prior, 2005). The 
253 HAT-based assays evaluate the ability of an antioxidant to quench free radicals by

254 hydrogen donation in a competitive reaction. These assays include ORAC, total radical 255 trapping antioxidant parameter (TRAP) and $\beta$-carotene bleaching assay. ET-based assays 256 measure the ability of a potential antioxidant to transfer one electron to reduce an oxidant, 257 so these reactions are $\mathrm{pH}$ dependent. The ABTS radical scavenging assay, ferric-reducing 258 antioxidant power, and DPPH radical scavenging activity are examples of ET-based 259 assays (Huang et al., 2005; McDonald-Wicks, Wood, \& Garg, 2006). Thus, the antioxidant activity was measured by two different HAT-based assays (ORAC and $\beta$ carotene bleaching assay) and three ET-based assays (DPPH radical scavenging activity, 262 ferric-reducing antioxidant power and ABTS radical scavenging assay). The obtained 263 results, before and after digestion of samples, are shown in Figures 1 and 2.

264 In the DPPH radical scavenging activity assay, the highest antioxidant activities were 265 obtained for samples cooked for $20 \mathrm{~min}$ and $1 \mathrm{~h}$, reaching percentage values of $53.05 \pm$ 2.03 and $64.89 \pm 1.51$, respectively (Figure 1A), when assayed at a concentration of 2.5 $\mathrm{mg} / \mathrm{mL}$. After digestion, no significant effect was observed in any sample, except in the case of the sample extracted with $\mathrm{H}_{2} \mathrm{O}$ that showed a notable increase at all the tested concentrations (Figure 1B). On the other hand, ferric-reducing antioxidant power assay revealed that the sample cooked at $100{ }^{\circ} \mathrm{C}$ for $20 \mathrm{~min}$ showed the highest absorbance measured at $700 \mathrm{~nm}$ for a concentration of $2.5 \mathrm{mg} / \mathrm{mL}$, indicating a significant higher antioxidant activity. However, all samples at $5 \mathrm{mg} / \mathrm{mL}$ reached maximum values around

273 1.5, with the exception of the sample extracted with $0.5 \mathrm{~N} \mathrm{HCl}(0.63 \pm 0.04)$ (Figure 1C).

274 After samples were digested using gastrointestinal enzymes, the antioxidant activity at 275 $2.5 \mathrm{mg} / \mathrm{mL}$ increased in samples extracted with $0.5 \mathrm{~N} \mathrm{HCl}, 0.01 \mathrm{~N} \mathrm{HCl}$ and $\mathrm{H}_{2} \mathrm{O}$, showing 276 no effect for cooked samples during $20 \mathrm{~min}$ or $1 \mathrm{~h}$. What is more, the sample $0.5 \mathrm{~N} \mathrm{HCl}$ 
displayed a marked increase on the antioxidant activity after the simulated digestion,

278 although it was the lowest value obtained (Figure 1D).

279 In contrast to the other methods, the $\beta$-carotene bleaching assay revealed that the sample

$2800.5 \mathrm{~N} \mathrm{HCl}$ presented the highest antioxidant capacity (91\%), followed by samples

281 subjected to cooking treatments that reached values around $85 \%$ (Figure 1E).

282 Nevertheless, the antioxidant activity after digestion was decreased significantly for the sample $0.5 \mathrm{~N} \mathrm{HCl}(75 \%)$ and the cooked at $100{ }^{\circ} \mathrm{C}$ for $1 \mathrm{~h}$ (from $85 \%$ to $63 \%$ ), whereas the activity of the sample $\mathrm{H}_{2} \mathrm{O}$ presented a sharp increase at the lowest concentrations tested in the assay (Figure 1F).

Figure 2A shows no statistically differences between samples before and after in vitro digestion in the ABTS radical scavenging assay, obtaining values between $187.47 \pm 13.72$ and $220.34 \pm 17.81 \mathrm{nmol}$ TEAC/mg sample. However, a significant increase in the antioxidant activity was observed for the sample extracted with $0.5 \mathrm{~N} \mathrm{HCl}$ after the simulated digestion. In the ORAC assay (Figure 2B), the highest value (230.22 \pm 6.59 nmol TE per mg) was obtained in the sample cooked at $100{ }^{\circ} \mathrm{C}$ during $20 \mathrm{~min}$, whereas

292 the antioxidant activity was considerably decreased after digestion with the exception of 293 the sample extracted with $0.5 \mathrm{~N} \mathrm{HCl}$.

294 Technological treatments such as mincing or cooking are particularly important in the development of oxidation and denaturation processes as they affect the structural properties and physic-chemical state of proteins and peptides (Liu \& Xiong, 2000; Santé-

297 Lhoutellier, Astruc, Marinova, Greve, \& Gatellier, 2008). Moreover, at high temperatures,

298 oxidation and aggregation of proteins can lead to an increase of surface hydrophobicity 299 that modify the rate of digestion by gastrointestinal enzymes depending on the nature of protease, temperature and time of cooking (Santé-Lhoutellier, Aubry, \& Gatellier, 2007;

301 Bax et al., 2012). In fact, recent studies showed that the temperature of cooking affects 
302 the digestion rate of proteins more than digestibility, showing that conformational

303 changes due to protein denaturation favored the bioaccessibility of the digestive proteases

304 to their cleavage sites (Sayd, Chambon, \& Santé-Lhoutellier, 2016). In this regard, some

305 studies have shown that cooking reduced the antioxidant capacity whereas simulated

306 digestion could lead to the formation of novel antioxidant peptides (Jensen, Dort, \&

307 Eilertsen, 2014; Remanan \& Wu, 2014). In the present study, samples subjected to 308 cooking showed higher antioxidant activity than uncooked samples in all methods 309 evaluated except for the ABTS radical scavenging assay. This fact evidences that there

310 has been no reduction, but rather an increase of potentially bioactive peptides after

311 household preparations using dry-cured ham bones. Nevertheless, the in vitro digestion

312 of samples showed no significant effect on the antioxidant activity. On the other hand,

313 regarding the evaluated effect of acid concentration on the extracted peptides, the low

314 values of antioxidant activity obtained indicate that more acidic conditions did not

315 increase the generation/extraction of a higher amount of peptides.

$316 \quad 3.2$ Peptide profile before and after digestion of samples

317 The gastrointestinal digestion has a key influence on the release of peptides from parent

318 proteins as well as on the modification or breakdown of peptides that can exert antioxidant 319 properties. In fact, enzymes specificity affects amount, size, composition of peptides and 320 their amino acid sequence, influencing the antioxidant activity of the digested samples

321 (Sarmadi \& Ismail, 2010; Samaranayaka \& Li-Chan, 2011). So, the analysis by MALDI-

322 TOF MS was used to evaluate the stability of the peptides to the digestion method,

323 comparing the peptide profile of samples before and after the in vitro digestion. As

324 illustrated in Figure 3, there is a larger amount of peptides with smaller mass in the 325 samples taken after the simulated digestion, suggesting the degradation of bigger sized 326 peptides into smaller ones by the action of the added enzymes. In particular, samples 
subjected to cooking at $100{ }^{\circ} \mathrm{C}$ during $1 \mathrm{~h}$ were those whose digestion was more noticeable,

328 showing a larger amount of peptides lower than 450 Da. In this regard, recent studies have shown that cooking treatments affect the digestion rate of proteins due to changes in their conformation that can modify the bioaccesibility of enzymes to their cleavage sites (Bax et al., 2012; Wen et al., 2015). However, this work revealed that the antioxidant activity of these cooked samples decreased for the ORAC and $\beta$-carotene bleaching assays, while the values obtained with the other antioxidant methods were not modified. These results could be explained by the fact that antioxidant activity is not only related to the size of the peptides but also to their amino acid composition, structure, and hydrophobicity (Chen, Muramoto, Yamauchi, Fujimoto, \& Nokihara, 1998). In this regard, a study done by Damgaard, Lametsch, and Otte (2015) showed that the antioxidant capacity of hydrolysed animal by-products was correlated with the amino acid composition, not with the amount of low molecular weight peptides. The aromatic amino acids Trp, Tyr, and Phe, as well as Cys, Met, and His have been reported to show high antioxidant activities through several mechanisms such as free radical scavengers,

342 reducing agents, metal chelators and inhibitors of lipid peroxidation (Samaranayaka \&

343 Li-Chan, 2011; Power, Jakeman, \& FitzGerald, 2013; Damgaard et al., 2015).

\section{$344 \quad 3.2$ Peptide profile of the digested cooked samples}

345 The peptide profile of samples subjected to cooking treatments and in vitro digestion was

346 fully characterised by analysing the samples through nLC-MS/MS for the identification

347 of peptides. The relative quantification of extracted peptides was performed using a label-

348 free method by extracting peak intensities. So, a total of 459 peptides derived from 57 349 proteins were identified and quantified to establish differences between the control 350 (extracted with $\mathrm{H}_{2} \mathrm{O}$ and no cooking treatment) and cooked samples (100 ${ }^{\circ} \mathrm{C} 20 \mathrm{~min}$, and 351 $100{ }^{\circ} \mathrm{C} 1 \mathrm{~h}$ ). To this end, a Principal Component Analysis (PCA) was carried out to assess 
352 the possible differences between samples and to obtain information on the most

353 influential peptides (see Figure 4). In fact, the PCA showed two statistically different

354 groups, being sample cooked at $100{ }^{\circ} \mathrm{C}$ for $1 \mathrm{~h}$ located in a different cluster of the other

355 two samples (Figure 4A). Component 1 is responsible for $52.9 \%$ of the variability in the

356 dataset, and Component 2 explains $20 \%$ of the variance within the dataset. Additionally,

357 the loading plot (Figure 4B) revealed all the peptides responsible for influencing the

358 clustering of data, being those derived from collagen protein the peptides showing the

359 greatest influence for the description of the two discriminant components. These peptides

360 were thus extracted for a new statistical analysis as shown in Figure 5. In this case, the

361 PCA showed three statistically different groups that match with the three different

362 treatments (Figure 5A). Component 1 explains $62.3 \%$ of the variability in the dataset,

363 which allows differentiating between samples cooked for $1 \mathrm{~h}$ from the other two samples.

364 On the other hand, Component 2 is responsible for $14.3 \%$ of the variance within the

365 dataset for these two discriminant components, discriminating between the control

366 sample and the sample cooked for 20 min. However, all the peptides do not show an

367 identical influence on the clustering so the loading plot (Figure 5B) revealed the main

368 responsible peptides for the observed differences, which are indicated with higher colour

369 density values. In this respect, Table 1 shows the sequences of those peptides mainly

370 responsible for the differences observed after digestion of sample cooked for $1 \mathrm{~h}$ at $100^{\circ} \mathrm{C}$.

371 The complete list of sequences that have been identified and relatively quantified using

372 the label-free approach is shown in Table 1_supplementary material.

373 Even though the digestion process leads to the breakdown of proteins, proteolysis is 374 greatly responsible for the generation of thousands of small peptides and free amino acids

375 due to the action of endogenous enzymes on sarcoplasmic and myofibrillar proteins and

376 collagen (Toldrá \& Flores, 1998). Figure 6 shows the percentage of peptides identified in 
377 the three digested samples (control, $100{ }^{\circ} \mathrm{C} 20 \mathrm{~min}$, and $100{ }^{\circ} \mathrm{C} 1 \mathrm{~h}$ ) from main proteins

378 of origin. As expected according to the observed PCA results, the largest percentage of 379 peptides was from collagen protein (61\%), including collagen $\alpha-1(\mathrm{I})$ chain, collagen $\alpha$ 380 1(II) chainlike partial, collagen $\alpha$-1(III) chain precursor, and collagen $\alpha-2(\mathrm{I})$ chain 381 precursor. In fact, collagen is an insoluble fibrous protein and is the major component of 382 some by-products such as bones, skin, cartilages and tendons (Gómez-Guillén, Giménez, 383 López-Caballero, \& Montero, 2011). When collagen is heated, its structure in triple helix 384 begins to unravel into single strands, shrinks and dissolves leading to a disruption of the 385 myosin gel and loss of its functional properties such as gelling and water-binding capacity (Tornberg, 2005; Voutila, Mullen, Ruusunen, Troy, \& Puolanne, 2007). Moreover, the enzymatic hydrolysis of collagen results in the release of many small peptides, some of them have been reported as bioactive peptides with ACE inhibitory and antioxidant activity. In this regard, some studies have identified antioxidant collagen peptides derived from hydrolysates of porcine skin (Li, Chen, Wang, Ji, \& Wu, 2007) and bovine tendon (Ryder, Bekhit, McConnell, \& Carne, 2016) as well as the naturally generated peptide GLAGA identified in dry-cured ham (Escudero, Mora, Fraser, Aristoy, \& Toldrá, 2013). What is more, collagen protein has repeated unique Gly-Pro-Hyp sequence on its structure, and observed antioxidant and antihypertensive activities have been associated with this unique peptide composition (Gómez-Guillén et al., 2011). So, due to the large amount of peptides identified from collagen in this work, they could be the main responsible for the antioxidant activity of samples. However, further research would be needed to

398 characterise the specific sequences responsible for the antioxidant activity in dry-cured 399 ham bones.

400

\section{Conclusions}


402 This study reports the presence of antioxidant peptides derived from dry-cured ham bones

403 which have been traditionally used in the Mediterranean household cooking of broths and

404 stews. In general, cooking increased the antioxidant activity whereas simulated

405

406

407

408

409

410

411

412

413

414

415

416

417

418

419

420

421

422

423

424

425

426 gastrointestinal digestion did not shown a significant effect on the antioxidant activity of samples despite the analysis of peptide profile by MALDI-TOF MS revealed the generation of novel peptides, mainly in the samples cooked at $100{ }^{\circ} \mathrm{C}$ for $1 \mathrm{~h}$. Moreover, a total of 459 peptides derived from 57 proteins of origin were identified and relatively quantified by LC-MS/MS, being the peptides derived from collagen the most influential to establish differences between uncooked and cooked samples after digestion. In conclusion, dry-cured ham bones appear to be a good source of antioxidant peptides after household cooking preparations and considering gastrointestinal digestion, giving an added-value to these by-products that was not considered to date.

\section{Acknowledgements}

Emerging Research Group Grant from Generalitat Valenciana in Spain (GV/2015/138) and Juan de la Cierva postdoctoral contract to LM are acknowledged. Grant Agreement 614281 (HIGHVALFOOD) and contract to MG are also acknowledged. The proteomic analysis was performed in the proteomics facility of SCSIE University of Valencia that belongs to ProteoRed, PRB2-ISCIII, (IPT13/0001 - ISCIII-SGEFI / FEDER).

\section{References}

Arvanitoyannis, I.S. \& Ladas, D. (2008). Meat waste treatment methods and potential uses. International Journal of Food Science \& Technology, 43 (3), 543-559.

Bax, M.L., Aubry, L., Ferreira, C., Daudin, J.D., Gatellier, P., Rémond, D., \& SantéLhoutellier, V. (2012). Cooking temperature is a key determinant of in vitro meat protein 
digestion rate: investigation of underlying mechanisms. Journal of Agricultural and Food

428 Chemistry, 60 (10), 2569-2576.

429 Bersuder, P., Hole, M., \& Smith, G. (1998). Antioxidants from heated histidine-glucose model system. I. Investigation of the antioxidant role of histidine and isolation of antioxidants by high performance liquid chromatography. Journal of the American Oil Chemist's Society, 75, 181-187.

433 Chen, H.M., Muramoto, K., Yamauchi, F., Fujimoto, K., \& Nokihara, K. (1998). 434 Antioxidative properties of histidine-containing peptides designed from peptide 435 fragments found in the digests of a soybean protein. Journal of Agricultural and Food Chemistry, 46 (1), 49-53.

437 Damgaard, T., Lametsch, R., \& Otte, J. (2015). Antioxidant capacity of hydrolyzed 438 animal by-products and relation to amino acid composition and peptide size distribution. 439 Journal of Food Science and Technology, 52 (10), 6511-6519.

440 Dávalos, A., Gómez-Cordovés, C., \& Bartolomé, B. (2004). Extending applicability of 441 the oxygen radical absorbance capacity (ORAC-fluorescein) assay. Journal of 442 Agricultural and Food Chemistry, 52, 48-54.

443 Di Bernardini, R., Harnedy, P., Bolton, D., Kerry, J., O’Neill, E., Mullen, A.M., \& Hayes, 444 M. (2011). Antioxidant and antimicrobial peptidic hydrolysates from muscle protein 445 sources and by-products. Food Chemistry, 124 (4), 1296-1307.

446 Escudero, E., Sentandreu, M.A., Arihara, K., \& Toldrá, F. (2010). Angiotensin I447 converting enzyme inhibitory peptides generated from in vitro gastrointestinal digestion 448 of pork meat. Journal of Agricultural and Food Chemistry, 58 (5), 2895-2901.

449 Escudero, E., Mora, L., Fraser, P.D., Aristoy, M.C., \& Toldrá, F. (2013). Identification 450 of novel antioxidant peptides generated in Spanish dry-cured ham. Food Chemistry, 138 $451 \quad$ (2-3), 1282-1288. 
452 Gallego, M., Mora, L., Aristoy, M.C., \& Toldrá, F. (2015a). Titin-derived peptides as

453 processing time markers in dry-cured ham. Food Chemistry, 167, 326-339.

454 Gallego, M., Mora, L., Aristoy, M.C., \& Toldrá, F. (2015b) Optimisation of a simple and 455 reliable label-free methodology for the relative quantitation of raw pork meat proteins. 456 Food Chemistry, 182, 74-80.

457 Gómez-Guillén, M.C., Giménez, B., López-Caballero, M.E., \& Montero, M.P. (2011).

458 Functional and bioactive properties of collagen and gelatin from alternative sources: A 459 review. Food Hydrocolloids, 25 (8), 1813-1827.

460 Huang, S.J., Tsai, S.Y., \& Mau, J.L. (2006). Antioxidant properties of methanolic extracts 461 from Agrocybe cylandrea. LWT - Food Science and Technology, 39, 378-386.

462 Huang, D., Ou, B., \& Prior, R.L. (2005). The chemistry behind antioxidant capacity 463 assays. Journal of Agricultural and Food Chemistry, 53, 1841-1856.

464 Jensen, I.J., Dort, J., \& Eilertsen, K.E. (2014). Proximate composition, antihypertensive 465 and antioxidative properties of the semimembranosus muscle from pork and beef after 466 cooking and in vitro digestion. Meat Science, 96 (2), 916-921.

467 Koleva, I.I., Van Beek, T.A., Linssen, J.P.H., De Groot, A., \& Evstatieva, L.N. (2002). 468 Screening of plant extracts for antioxidant activity: A comparative study on three testing 469 methods. Phytochemical Analysis, 13, 8-17.

470 Lafarga, T., \& Hayes, M. (2014). Bioactive peptides from meat muscle and by-products: 471 generation, functionality and application as functional ingredients. Meat Science, 98 (2), $472 \quad 227-239$.

473 Li, B., Chen, F., Wang, X., Ji, B., \& Wu, Y. (2007). Isolation and identification of 474 antioxidative peptides from porcine collagen hydrolysate by consecutive chromatography 475 and electrospray ionization-mass spectrometry. Food Chemistry, 102 (4), 1135-1143. 
Liu, G., \& Xiong, Y.L. (2000). Electrophoretic pattern, thermal denaturation, and in vitro

477 digestibility of oxidized myosin. Journal of Agricultural and Food Chemistry, 48 (3),

478

479

480

481

482

483

484

485

486

487

488

489

490

491

492

493

494

495

496

497

498

499

500 624-630.

MacDonald-Wicks, L.K., Wood, L.G., \& Garg, M.L. (2006). Methodology for the determination of biological antioxidant capacity in vitro: a review. Journal of the Science of Food and Agriculture, 86, 2046-2056.

Minekus, M., Alminger, M., Alvito, P., Ballance, S., Bohn, T., Bourlieu, C., et al. (2014). A standardised static in vitro digestion method suitable for food - an international consensus. Food \& Function, 5, 1113-1124.

Mora, L., Reig, M., \& Toldrá, F. (2014). Bioactive peptides generated from meat industry by-products. Food Research International, 65, 344-349.

Power, O., Jakeman, P., \& FitzGerald, R.J. (2013). Antioxidative peptides: enzymatic production, in vitro and in vivo antioxidant activity and potential applications of milkderived antioxidative peptides. Amino acids, 44, 797-820.

Re, R., Pellegrini, N., Proteggente, A., Pannala, A., Yang, M., \& Rice-Evans, C. (1999). Antioxidant activity applying an improved ABTS radical cation decolorization assay. Free Radical Biology and Medicine, 26 (9), 1231-1237.

Remanan, M.K., \& Wu, J. (2014). Antioxidant activity in cooked and simulated digested eggs. Food \& Function, 5 (7), 1464-1474.

Ryder, K., Bekhit, A.E.D., McConnell, M., \& Carne, A. (2016). Towards generation of bioactive peptides from meat industry waste proteins: Generation of peptides using commercial microbial proteases. Food Chemistry, 208, 42-50.

Samaranayaka, A.G.P., \& Li-Chan, E.C.Y. (2011). Food-derived peptidic antioxidants: A review of their production, assessment, and potential applications. Journal of Functional Foods, 3, 229-254. 
501 Santé-Lhoutellier, V., Aubry, L., \& Gatellier, P. (2007). Effect of oxidation on in vitro

502 digestibility of skeletal muscle myofibrillar proteins. Journal of Agricultural and Food 503 Chemistry, 55 (13), 5343-5348.

504 Santé-Lhoutellier, V., Astruc, T., Marinova, P., Greve, E., \& Gatellier, P. (2008). Effect 505 of meat cooking on physicochemical state and in vitro digestibility of myofibrillar 506 proteins. Journal of Agricultural and Food Chemistry, 56 (4), 1488-1494.

507 Sarmadi, B.H., \& Ismail. A. (2010). Antioxidative peptides from food proteins: A review. 508 Peptides, 31, 1949-1956.

509 Sayd, T., Chambon, C. \& Santé-Lhoutellier, V. (2016). Quantification of peptides 510 released during in vitro digestion of cooked meat. Food Chemistry, 197, 1311-1323.

511 Toldrá, F., \& Flores, M. (1998). The role of muscle proteases and lipases in flavour 512 development during the processing of dry-cured ham. Critical Reviews in Food Science 513 and Nutrition, 38 (4), 331-352.

514 Toldrá, F., \& Reig, M. (2011). Innovations for healthier processed meats. Trends in Food 515 Science \& Technology, 22, 517-522.

516 Toldrá, F., Aristoy, M.C., Mora, L., \& Reig, M. (2012). Innovations in value-addition of 517 edible meat by-products. Meat Science, 92, 290-296.

518 Tornberg, E. (2005). Effects of heat on meat proteins - Implications on structure and 519 quality of meat products. Meat Science, 70 (3), 493-508.

520 Vercruysse, L., Van Camp, J., \& Smagghe, G. (2005). ACE inhibitory peptides derived 521 from enzymatic hydrolysate of animal protein: A review. Journal of Agricultural and 522 Food Chemistry, 53, 8106-8115.

523 Voutila, L., Mullen, A.M., Ruusunen, M., Troy, D., \& Puolanne, E. (2007). Thermal 524 stability of connective tissue from porcine muscles. Meat Science, 76 , 474-480. 
525 Wen, S., Zhou, G., Li, L., Xu, X., Yu, X., Bai, Y., \& Li, C. (2015). Effect of cooking on

526 in vitro digestion of pork proteins: a peptidomic perspective. Journal of Agricultural and 527 Food Chemistry, 63, 250-261.

528 Zhang, W., Xiao, S., Samaraweera, H., Lee, E. J., \& Ahn, D. U. (2010). Improving

529 functional value of meat products. Meat Science, 86, 15-31.

530 Zhu, C.Z., Zhang, W.G., Zhou, G.H., \& Xu, X.L. (2016). Identification of antioxidant

531 peptides of Jinhua ham generated in the products and through the simulated gastrointestinal digestion system. Journal of the Science of Food and Agriculture, 96, 99108.

\section{FIGURE CAPTIONS}

536 Figure 1. Antioxidant activities of the five samples $\left(0.5 \mathrm{~N} \mathrm{HCl}, 0.01 \mathrm{~N} \mathrm{HCl}, \mathrm{H}_{2} \mathrm{O}, 100\right.$ ${ }^{\circ} \mathrm{C}$ 20min, $100{ }^{\circ} \mathrm{C} 1 \mathrm{~h}$ ) before and after the in vitro digestion determined using three different methods: DPPH radical scavenging activity, Ferric-reducing antioxidant power, and $\beta$-carotene bleaching assay. The values represent means of three replicates \pm standard

540 deviations.

541 Figure 2. Antioxidant activities of the five samples $\left(0.5 \mathrm{~N} \mathrm{HCl}, 0.01 \mathrm{~N} \mathrm{HCl}, \mathrm{H}_{2} \mathrm{O}, 100\right.$

$542{ }^{\circ} \mathrm{C} 20 \mathrm{~min}, 100{ }^{\circ} \mathrm{C} 1 \mathrm{~h}$ ) before and after the in vitro digestion determined using A) ABTS

543 radical scavenging capacity, and B) Oxygen radical absorbance capacity assay. Bars

544 represent standard deviations from three replicates. The values represent means of three

545 replicates \pm standard deviations, and bar letters indicate significant differences among the 546 values at $\mathrm{p}<0.05$.

547 Figure 3. MALDI-ToF mass spectra of the samples $\left(0.5 \mathrm{~N} \mathrm{HCl}, 0.01 \mathrm{~N} \mathrm{HCl}, \mathrm{H}_{2} \mathrm{O}, 100\right.$

$548{ }^{\circ} \mathrm{C} 20 \mathrm{~min}, 100{ }^{\circ} \mathrm{C} 1 \mathrm{~h}$ ) before digestion (B.D.) and after digestion (A.F.). 
549 Figure 4. A) Principal Component Analysis (PCA) score plot to assess the variance

550 among all the peptides of samples $\mathrm{H}_{2} \mathrm{O}, 100{ }^{\circ} \mathrm{C} 20 \mathrm{~min}$, and $100{ }^{\circ} \mathrm{C} 1 \mathrm{~h}$ in three replicates

551 (n=3). B) PCA loading plot showing the proteins of origin of those peptides more

552 responsible for main differences between samples.

553 Figure 5. A) Principal Component Analysis (PCA) score plot to assess the variance

554 among the peptides derived from collagen protein of samples $\mathrm{H}_{2} \mathrm{O}, 100{ }^{\circ} \mathrm{C} 20 \mathrm{~min}$, and

$555100{ }^{\circ} \mathrm{C} 1 \mathrm{~h}$ in three replicates (n=3). B) PCA loading plot showing peptides from collagen

556 protein. Higher colour density values indicate those peptides more responsible for

557 influencing the clustering of data.

558 Figure 6. Distribution of the 459 peptides identified by nLC-MS/MS according to their

55957 protein of origin.

560

561

562

563

564

565

Table 1

566 Sequences of collagen peptides responsible for main differences between control and

567 samples cooked for $20 \mathrm{~min}$ and $1 \mathrm{~h}$ at $100^{\circ} \mathrm{C}$, as is shown in the loading plot of the PCA

568 analysis. All the reported sequences are located in the Q1 of the loading plot. Data of

569 other sequences identified have been included in Supplementary material_Table 1.

\begin{tabular}{lccc}
\hline & & \multicolumn{2}{c}{ Location $^{\mathbf{a}}$} \\
\cline { 3 - 4 } Peptide sequence* & Collagen chain & M1.p[1] & M1.p[2] \\
\hline GIP[Oxi]GPAGAAGATGA & $\alpha-2(\mathrm{I})$ & 0.072 & 0.000 \\
GLTGPIGPP[Oxi]GP[Oxi]AGAP[Oxi]GDKGETGPSGPAGPTGA & $\alpha-1(\mathrm{I})$ & 0.072 & 0.001 \\
GISVPGPMGPSGPR & $\alpha-1(\mathrm{I})$ & 0.067 & 0.002 \\
NGPVGPTGPVGA & $\alpha-2(\mathrm{I})$ & 0.073 & 0.006 \\
GDGGPP[Oxi]GATGFP[Oxi]GAAGR & $\alpha-2(\mathrm{I})$ & 0.077 & 0.007 \\
GNDGSVGPVGPAGPIGSAGPP[Oxi]GFP[Oxi]GAP[Oxi]GP[Oxi]K & $\alpha-2(\mathrm{I})$ & 0.077 & 0.007 \\
NGETGPQGPPGPTGPGGDK & $\alpha-1(\mathrm{III})$ & 0.077 & 0.009 \\
QGPP[Oxi]GPP[Oxi]GSP[Oxi]GEQGPSGA & $\alpha-1(\mathrm{I})$ & 0.076 & 0.009 \\
QGPAGEP[Oxi]GEP[Oxi]GQTGPAGA & $\alpha-2(\mathrm{I})$ & 0.075 & 0.010 \\
TGETGASGPP[Oxi]GFAGEK & $\alpha-2(\mathrm{I})$ & 0.073 & 0.011
\end{tabular}


GETGPAGPAGPVGPVGAR

$\alpha-1(\mathrm{I}) \quad 0.076 \quad 0.012$

GIPGP[Oxi]AGAAGATGA

GEHGPP[Oxi]GPAGFP[Oxi]GAP[Oxi]GQNGEP[Oxi]GAK

$\alpha-2(\mathrm{I})$

$0.071 \quad 0.013$

GELGPVGNP[Oxi]GPAGPAGPR

P[Oxi]GPAGAAGAP[Oxi]GPQGAVGPAGK

EKGSP[Oxi]GADGPAGAP[Oxi]GTPGPQ

GEP[Oxi]GAAGPQGPP[Oxi]GPSGE

GEP[Oxi]GSP[Oxi]GENGAPGQM[2Ox]GPR

GESGPAGPP[Oxi]GAP[Oxi]GAP[Oxi]GAPGPVGPAGK

$\alpha-1($ III)

$0.077 \quad 0.013$

$\alpha-2(\mathrm{I}) \quad 0.077 \quad 0.015$

$\alpha-2(\mathrm{I}) \quad 0.076 \quad 0.016$

$\alpha-1(\mathrm{I}) \quad 0.074 \quad 0.017$

$\alpha-2$ (I) $\quad 0.069 \quad 0.017$

$\alpha-1(\mathrm{I}) \quad 0.068 \quad 0.018$

$\alpha-1(\mathrm{I}) \quad 0.074 \quad 0.018$

GPP[Oxi]GAVGNP[Oxi]GVNGAP[Oxi]GEAGR

GAP[Oxi]GTAGPSGPSGLPGER

HGDQGAPGPVGPAGPR

$\alpha-2(\mathrm{I})$

$\alpha-2(\mathrm{I})$

$\alpha-2(\mathrm{I})$

GEVGPAGPNGF

$\alpha-2(\mathrm{I})$

$\alpha-2(\mathrm{I})$

GENGPVGPTGPVGA

GAP[Oxi]GTAGPSGPSGLP[Oxi]GER

PGQ.QGPAGEP[Oxi]GEP[Oxi]GQTGPAGA

GSP[Oxi]GADGPAGAP[Oxi]GTPGPQ

P[Oxi]GEQGVP[Oxi]GDLGAP[Oxi]GPSGA

GPNGEVGSAGPP[Oxi]GPP[Oxi]GL

GEPGP[Oxi]P[Oxi]GPAGAAGPAGNP[Oxi]GADGQP[Oxi]GGK

GEP[Oxi]GPPGP[Oxi]AGAAGPAGNP[Oxi]GADGQPGGK

GPTGPIGPP[Oxi]GPAGQP[Oxi]GDK

GEP[Oxi]GAAGPQGPP[Oxi]GPSGEEGK

GESGAP[Oxi]GLP[Oxi]GIAGPR

NGETGPQGPP[Oxi]GPTGPGGDK

GNDGSVGPVGPAGPIGS

GLTGPIGPP[Oxi]GPAGAN[Dea]GEK

GEQGPAGSP[Oxi]GFQ

GESGPAGPP[Oxi]GAP[Oxi]GAP[Oxi]GAP[Oxi]GPVGPA

PGQ.QGPP[Oxi]GPP[Oxi]GSP[Oxi]GEQGPSGASGPAGPR

GP[Oxi]PGPM[Oxi]GPP[Oxi]GLAGPP[Oxi]GESG

GETGPAGPAGAPGP[Oxi]AGSR

PGQ.QGP[Oxi]PGEP[Oxi]GEP[Oxi]GASGPMGPR

GENGSP[Oxi]GAP[Oxi]GAP[Oxi]GHPGPPGP[Oxi]VGPAGK

DGPP[Oxi]GPP[Oxi]GSSGAP[Oxi]GSP[Oxi]GVSGPK

GSPGP[Oxi]QGPP[Oxi]GAP[Oxi]GPGGISGITGA

DGLNGLP[Oxi]GPIGP[Oxi]PGP[Oxi]R

GEP[Oxi]GPPGP[Oxi]AGAAGPAGNP[Oxi]GADGQP[Oxi]GGK

GEAGAQGPP[Oxi]GPAGPAGER

GPAGPP[Oxi]GPP[Oxi]GAAGTP[Oxi]GLQGM[2Ox]PGER

LGPVGNP[Oxi]GPAGPAGPR

GEP[Oxi]GPP[Oxi]GPAGAAGPAGNP[Oxi]GADGQP[Oxi]GGK

P[Oxi]GEAGPP[Oxi]GPP[Oxi]GPAGE

TGDAGPVGPP[Oxi]GPP[Oxi]GPP[Oxi]GPP[Oxi]GPPSGGFD

QGPP[Oxi]GEP[Oxi]GQAGPAGPPGP[Oxi]P[Oxi]GAIGPSGPAGK

LQGPP[Oxi]GP[Oxi]PGSP[Oxi]GEQGPSGASGPAGPR

GNDGSVGPVGPAGPIGSAGPPGFPGAPGPKGELGPVGNPGPAGPAGPRGEV

EGPAGLP[Oxi]GIDGR

GAAGLP[Oxi]GVAGAP[Oxi]GLP[Oxi]GPR

GAAGLP[Oxi]GVAGAP[Oxi]GLPGP[Oxi]R

GLTGPIGPPGP[Oxi]AGAN[Dea]GEK

P[Oxi]GEAGPP[Oxi]GPPGP[Oxi]AGEK

QGLP[Oxi]GPAGPP[Oxi]GEAGK

QGPP[Oxi]GPP[Oxi]GSP[Oxi]GEQGPSGASGPAGPR

GDAGPP[Oxi]GPAGPTGPP[Oxi]GPIGS

GEP[Oxi]GAP[Oxi]GENGTPGQTGAR

AGPAGPNGPP[Oxi]GPAGSR

GSQGSQGPAGPP[Oxi]GPP[Oxi]GPP[Oxi]GPP[Oxi]GPSGGGY

GDAGPP[Oxi]GPAGPTGPP[Oxi]GPIGSVGAP[Oxi]GP[Oxi]K

GDAGPP[Oxi]GPAGPTGPP[Oxi]GP[Oxi]IGSVGAPGP[Oxi]K

GEP[Oxi]GAP[Oxi]GENGTP[Oxi]GQTGAR

$\alpha-2(\mathrm{I})$

$\alpha-2(\mathrm{I})$

$\alpha-1(\mathrm{I})$

$\alpha-1$ (I)

$\alpha-2(\mathrm{I})$

$\alpha-1(\mathrm{I})$

$\alpha-1(\mathrm{I})$

$\alpha-1$ (III)

$\alpha-2(\mathrm{I})$

$\alpha-1$ (III)

$\alpha-1($ III)

$\alpha-2$ (I)

$\alpha-1(\mathrm{I})$

$\alpha-1(\mathrm{I})$

$\alpha-1$ (I)

$\alpha-1(\mathrm{I})$

$\alpha-1(\mathrm{I})$

$\alpha-1($ III)

$\alpha-1(\mathrm{I})$

$\alpha-1$ (III)

$\alpha-1$ (III)

$\alpha-1($ III)

$\alpha-1$ (I)

$\alpha-1$ (I)

$\alpha-1(\mathrm{I})$

$\alpha-1$ (III)

$\alpha-2(I)$

$\alpha-1(\mathrm{I})$

$\alpha-1(\mathrm{I})$

$\alpha-1(\mathrm{I})$

$\alpha-1$ (III)

$\alpha-1(\mathrm{I})$

$\alpha-2(\mathrm{I})$

$\alpha-2(\mathrm{I})$

$\alpha-2(\mathrm{I})$

$\alpha-2(\mathrm{I})$

$\alpha-1$ (I)

$\alpha-1(\mathrm{I})$

$\alpha-1(\mathrm{I})$

$\alpha-1(\mathrm{I})$

$\alpha-1(\mathrm{I})$

$\alpha-2(\mathrm{I})$

$\alpha-2(\mathrm{I})$

$\alpha-2(\mathrm{I})$

$\alpha-1(\mathrm{I})$

$\alpha-1(\mathrm{I})$

$\alpha-2(\mathrm{I})$ 
GLP[Oxi]GPAGPP[Oxi]GEAGK

$\alpha-1(\mathrm{I}) \quad 0.074 \quad 0.049$

SGLQGP[Oxi]P[Oxi]GPP[Oxi]GSP[Oxi]GEQGPSGASGPAGPR

$\alpha-1(\mathrm{I}) \quad 0.072$

0.049

GLTGPIGPP[Oxi]GPAGAP[Oxi]GDK

$\alpha-1(\mathrm{I})$

$0.074 \quad 0.049$

GEP[Oxi]GVLGAP[Oxi]GTAGPSGPSGLP[Oxi]GER

$\alpha-2(\mathrm{I})$

$0.073 \quad 0.050$

SGLQGPP[Oxi]GPP[Oxi]GSP[Oxi]GEQGPSGA

PGQ.QGPP[Oxi]GEP[Oxi]GEPGASGPM[2Ox]GPR

$\alpha-1(\mathrm{I})$

$0.073 \quad 0.050$

GPP[Oxi]GAVGAP[Oxi]GPQGF

$\alpha-1(\mathrm{I})$

$0.074 \quad 0.051$

QGPPGEP[Oxi]GEP[Oxi]GASGPM[Oxi]GPR

QGPP[Oxi]GEP[Oxi]GEP[Oxi]GASGP[Oxi]MGPR

$\alpha-2(\mathrm{I})$

$0.074 \quad 0.051$

$\alpha-1(\mathrm{I}) \quad 0.074 \quad 0.051$

$\alpha-1(\mathrm{I}) \quad 0.074 \quad 0.052$

$\alpha-2$ (I) $\quad 0.073 \quad 0.052$

$\alpha-2$ (I) $\quad 0.074 \quad 0.052$

PGQ.QGPAGEP[Oxi]GEP[Oxi]GQTGPAGAR

QGPAGEP[Oxi]GEP[Oxi]GQTGPAGAR

SGLQGPP[Oxi]GPP[Oxi]GSP[Oxi]GEQGPSGASGPAGPR

$\alpha-2(\mathrm{I})$

$0.073 \quad 0.053$

$\alpha-1(\mathrm{I}) \quad 0.074 \quad 0.053$

$\alpha-1(\mathrm{I}) \quad 0.074 \quad 0.053$

$\alpha-1(\mathrm{I}) \quad 0.073 \quad 0.053$

GDAGPP[Oxi]GPAGPTGPP[Oxi]GPIGSVGAP[Oxi]GPK

$\alpha-2(\mathrm{I}) \quad 0.066 \quad 0.053$

GEQGPAGPP[Oxi]GFQGLP[Oxi]GPAGT

AGP[Oxi]PGPTGPAGPP[Oxi]GFP[Oxi]GAVGA

$\alpha-1(\mathrm{I}) \quad 0.073$

$\alpha-1(\mathrm{I}) \quad 0.071$

$\alpha-1(\mathrm{I}) \quad 0.073$

TGDAGPVGPP[Oxi]GPP[Oxi]GPP[Oxi]GPP[Oxi]GPPSGGF

$\alpha-1(\mathrm{I})$

0.054

GSP[Oxi]GADGPAGAP[Oxi]GTP[Oxi]GPQ

$\alpha-1(\mathrm{I})$

$\alpha-1(\mathrm{III})$

GENGLP[Oxi]GENGAP[Oxi]GPM[Oxi]GPR

GPP[Oxi]GPM[Oxi]GPP[Oxi]GLAGPP[Oxi]GESGR

$\alpha-1(\mathrm{I})$

GETGPAGPAGPVGPV

$\alpha-1(\mathrm{I}) \quad 0.070$

$\alpha-1(\mathrm{I}) \quad 0.070$

$\alpha-2(\mathrm{I}) \quad 0.070$

GNDGSVGPVGPAGPIG

$\alpha-1$ (I) $\quad 0.071$

$\alpha-1(\mathrm{I}) \quad 0.070$

$\alpha-1(\mathrm{I}) \quad 0.073$

$\alpha-1(\mathrm{I}) \quad 0.073$

$\alpha-2(\mathrm{I}) \quad 0.071$

$\alpha-1(\mathrm{I}) \quad 0.072$

$\alpha-1(\mathrm{I}) \quad 0.072$

$\alpha-2(\mathrm{I}) \quad 0.070$

$\alpha-1(\mathrm{I}) \quad 0.071$

$\alpha-1(\mathrm{I})$

0.069

0.053

0.054

0.054

0.055

0.055

0.055

0.055

0.056

0.056

0.056

0.057

0.058

0.058

0.059

0.059

0.060

0.061

0.064

GPP[Oxi]GPAGAP[Oxi]GPQGF

*[Oxi] means that the previous residue has been oxidised. [Dea] means that the previous residue has been deamidated.
a- Location of the sequence in the Principal Component Analysis loading plot. All reported sequences are located in Q1. 


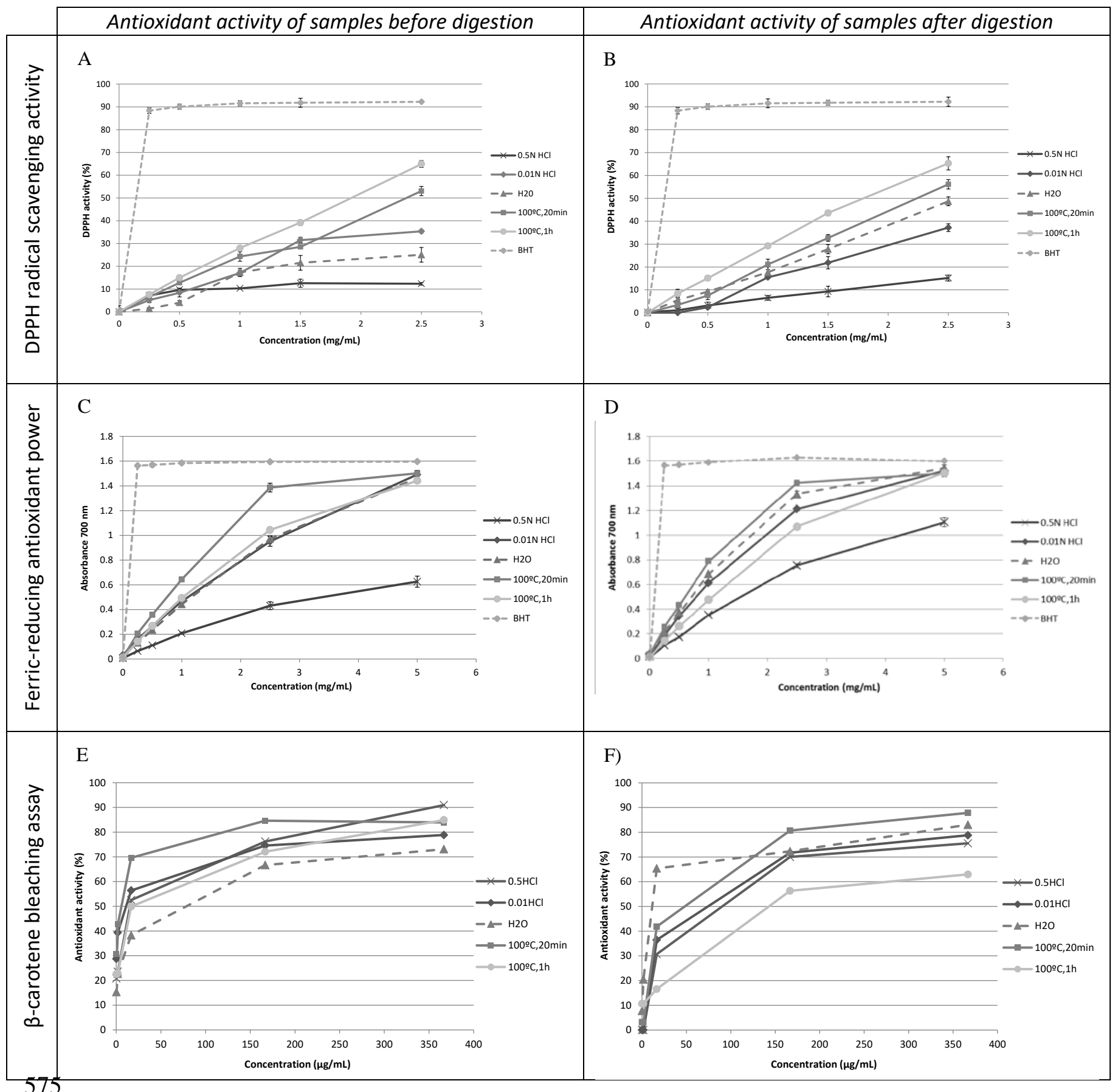




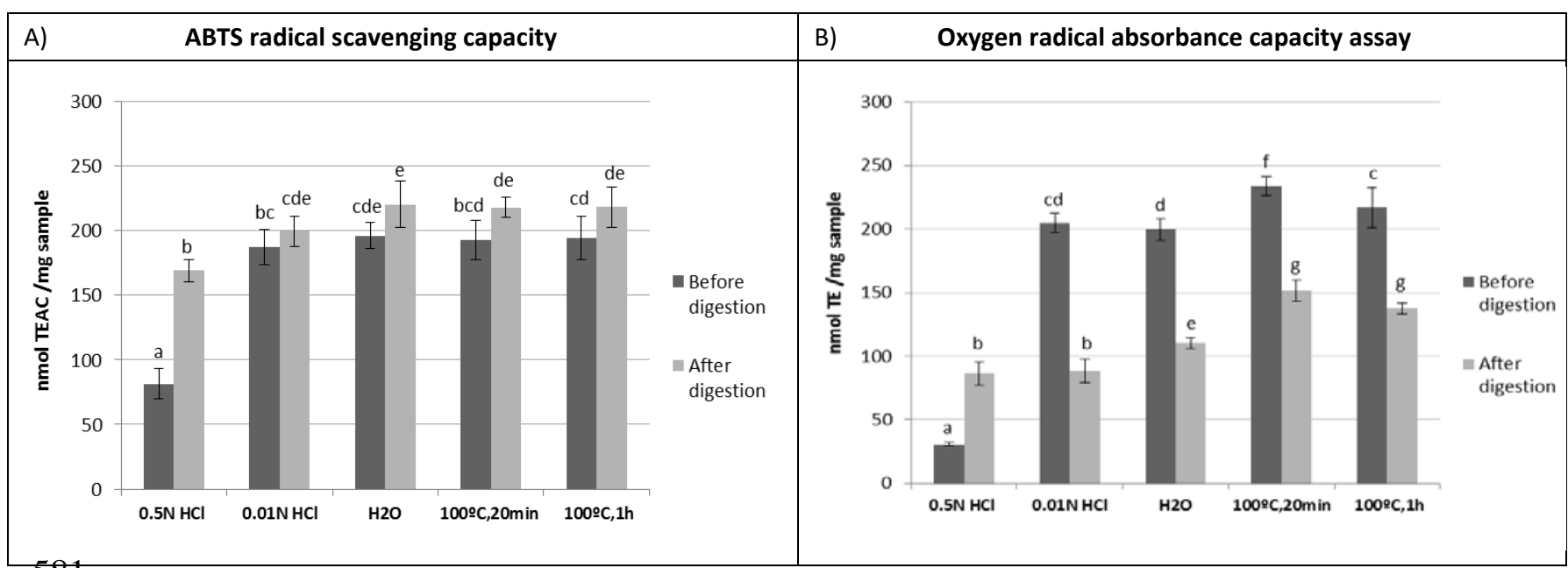

581

582

583

584 


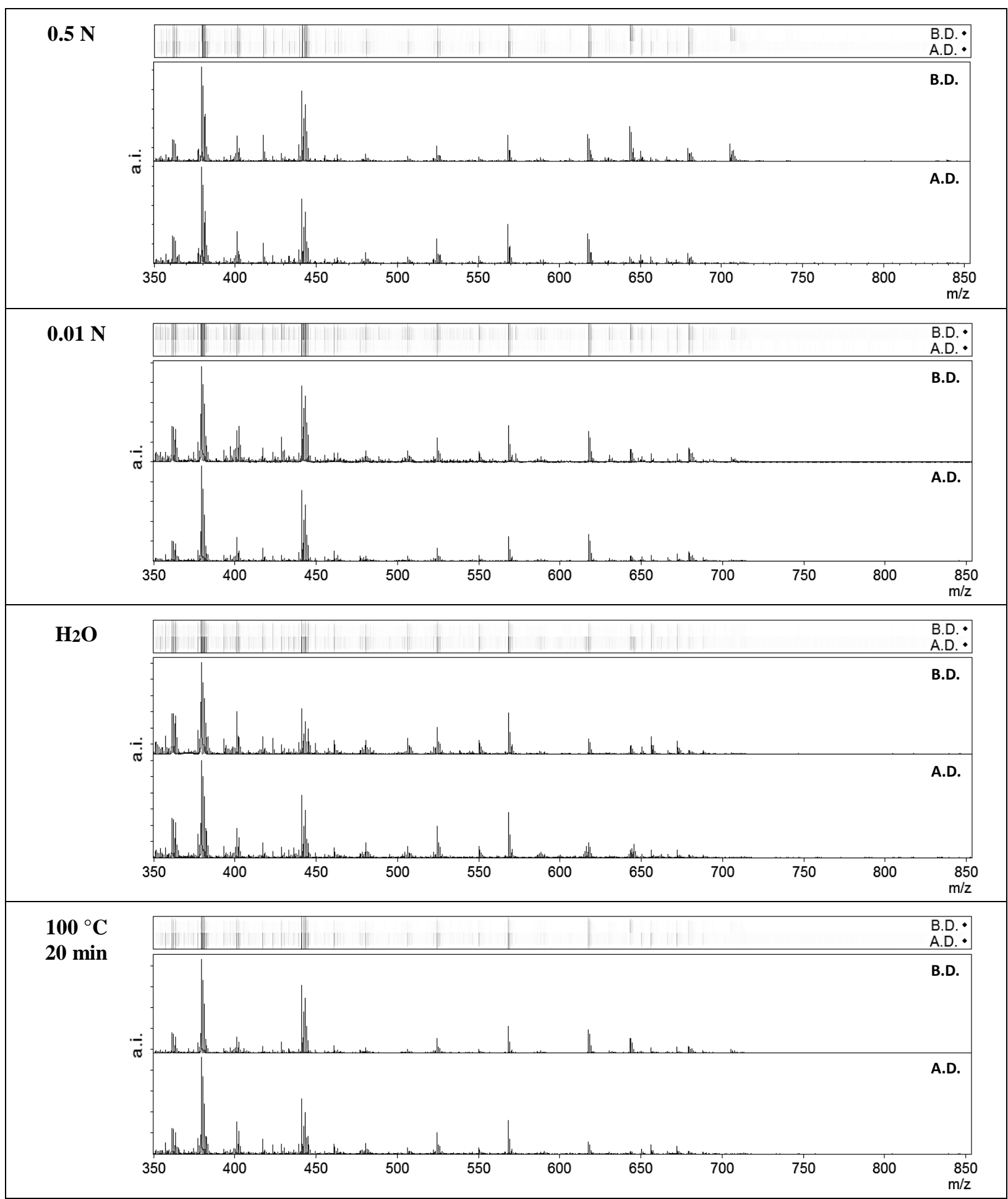


587

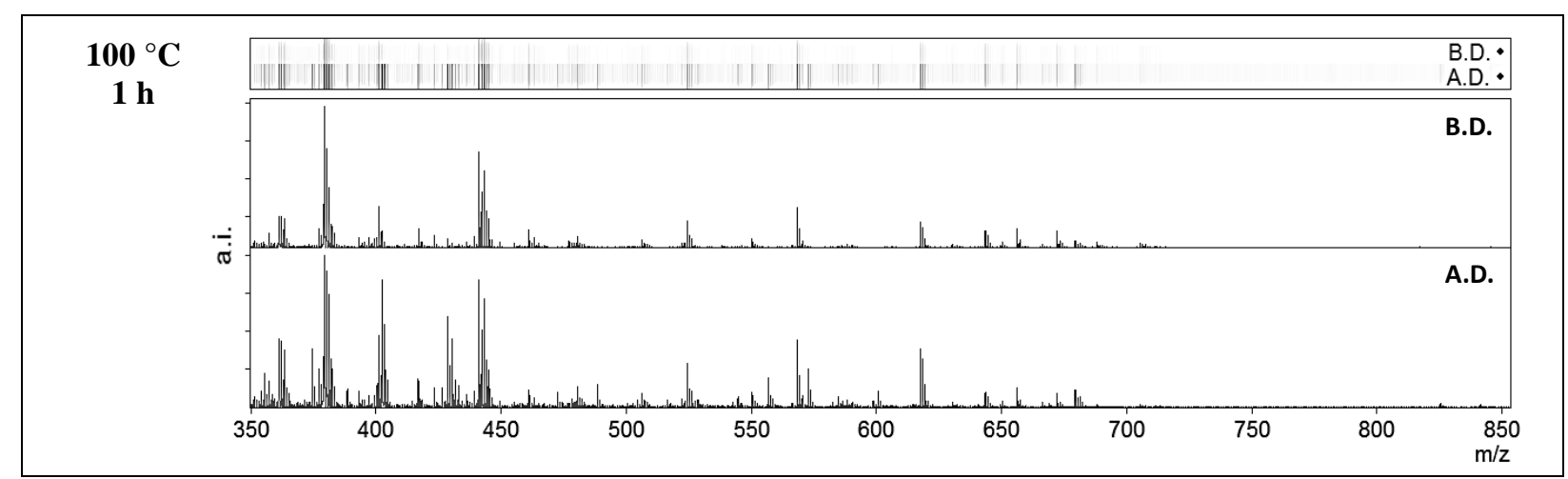

588

589 

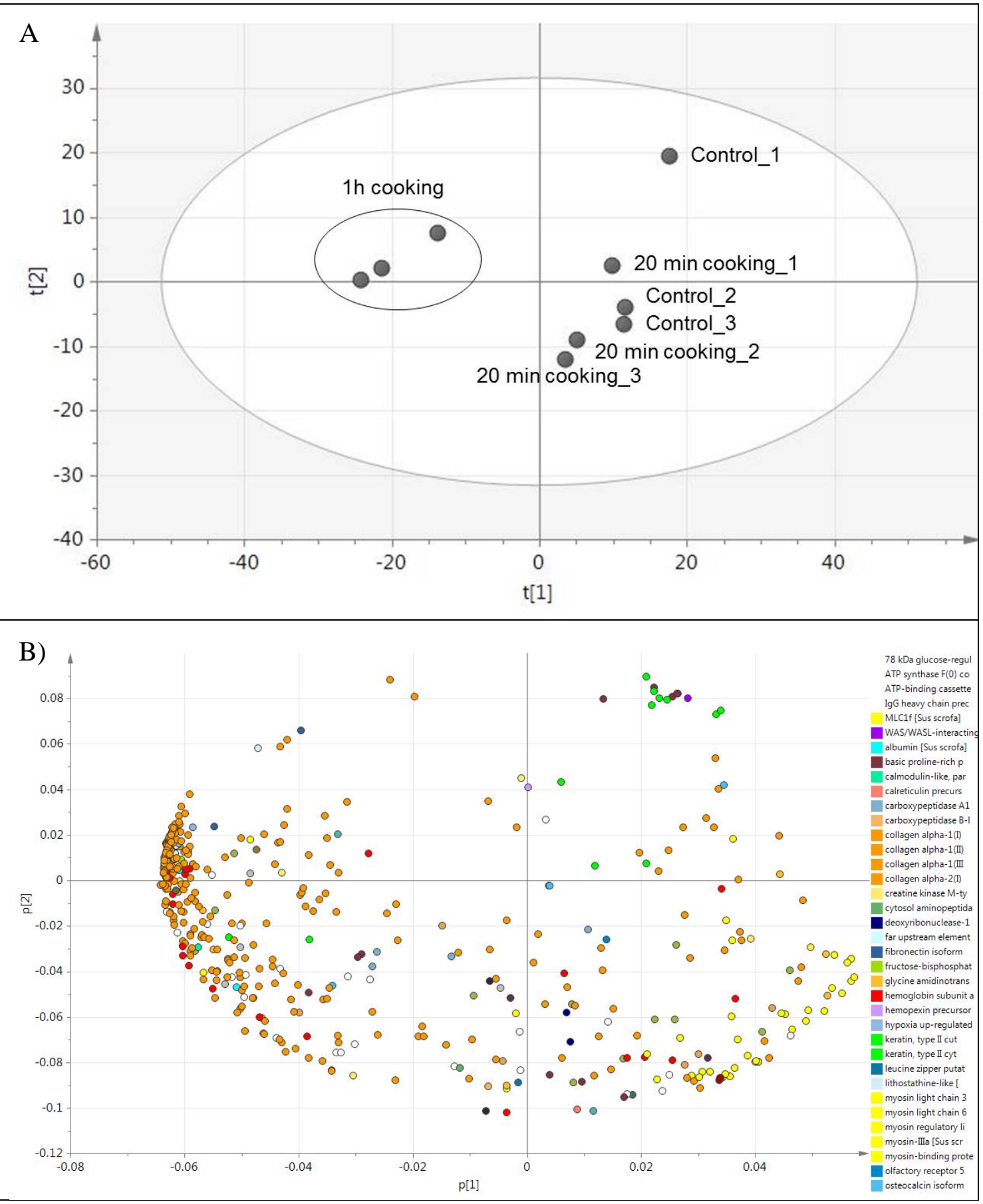


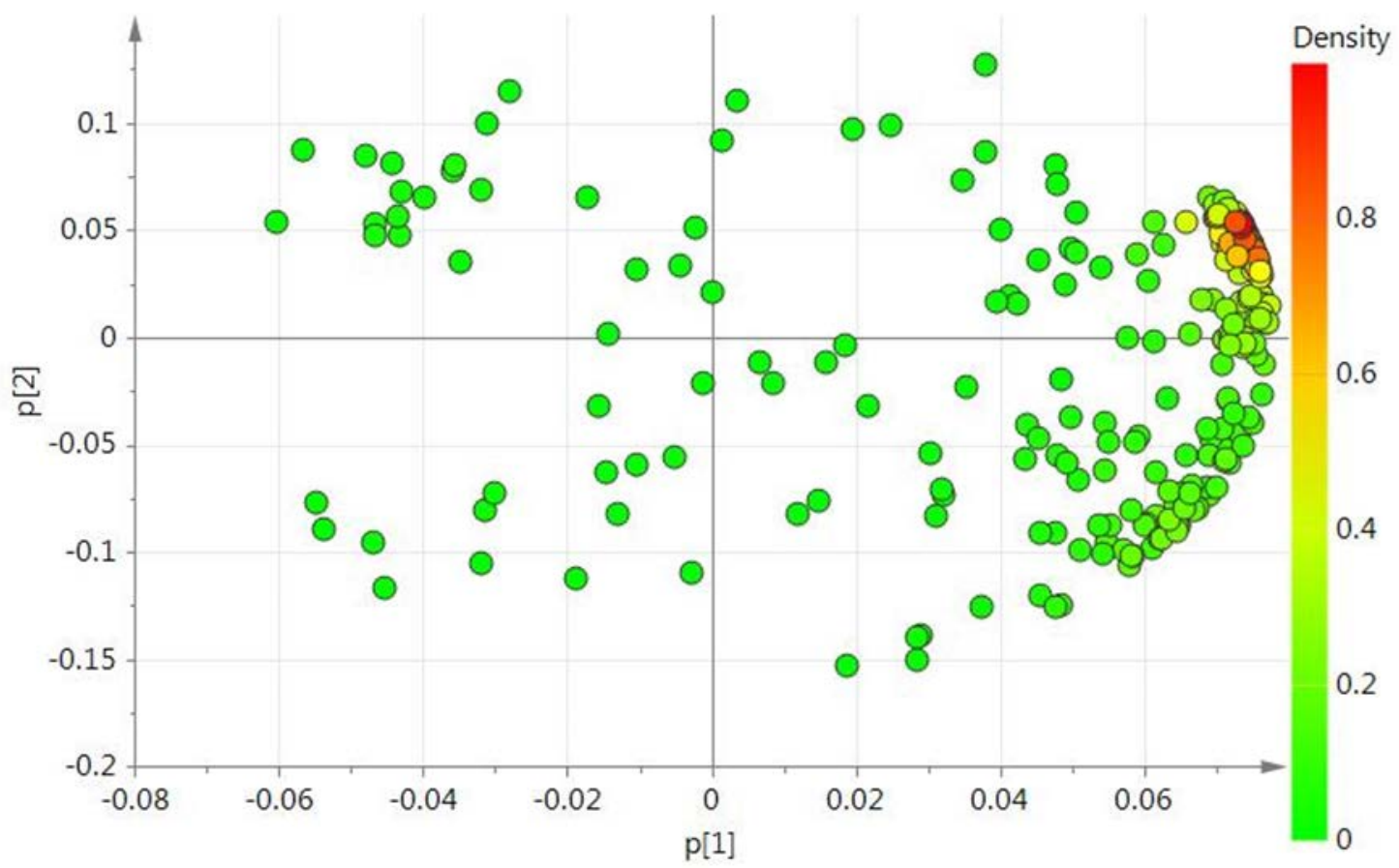

597

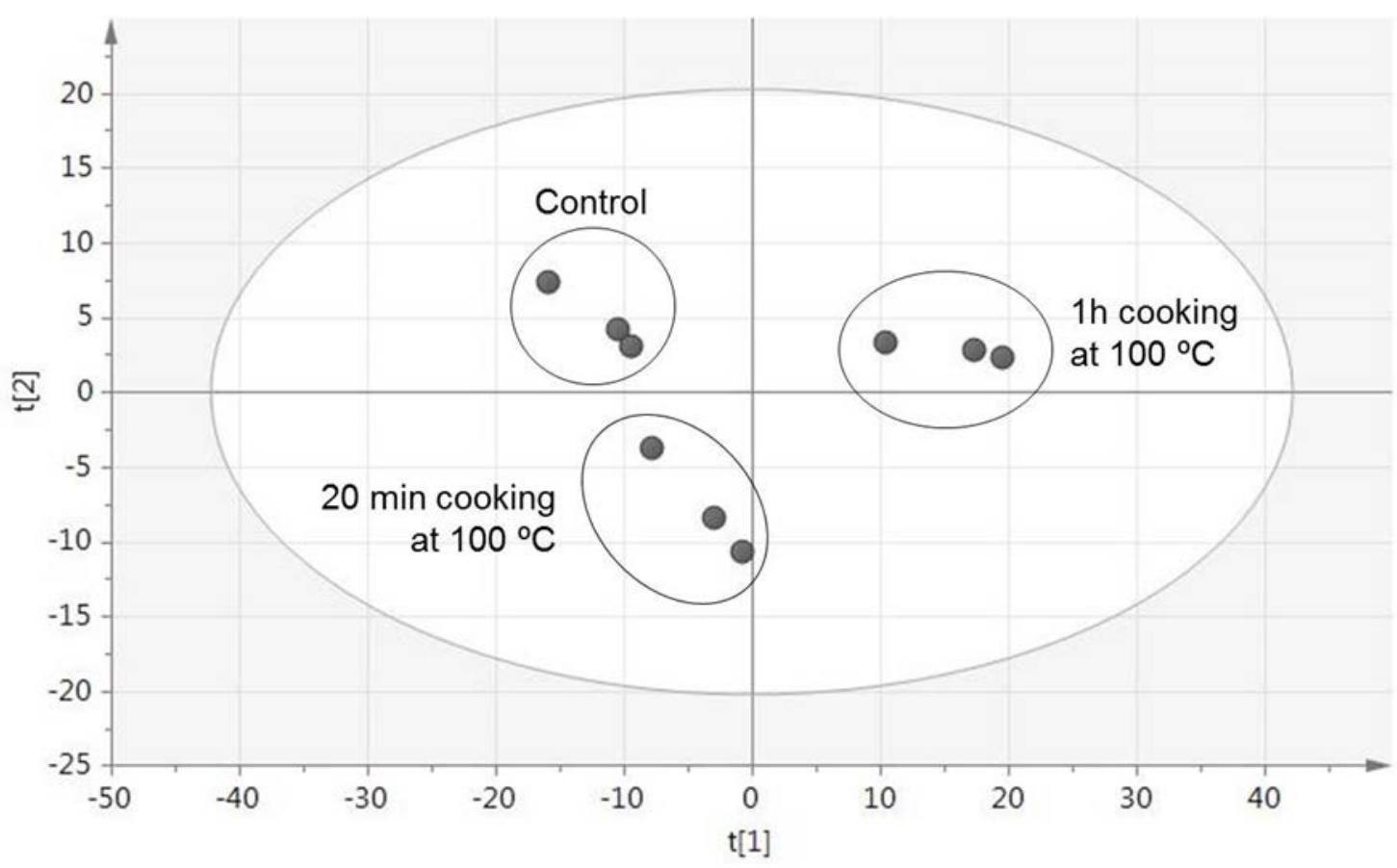

598

599 


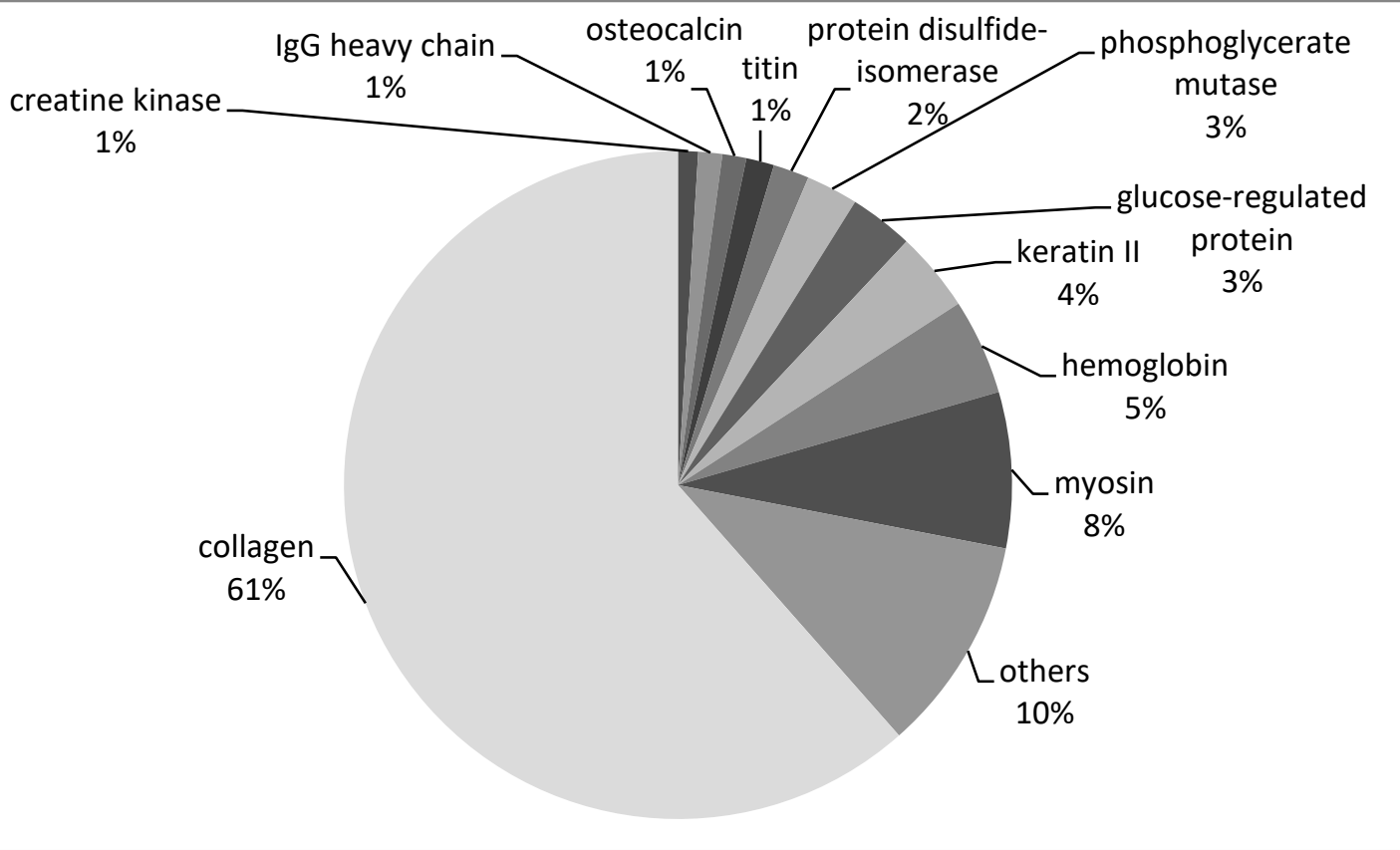

603

604 